\title{
Bank-Based Versus Market Based Financial System: Does it Really Matter?
}

\author{
Basak Turan İcke* Mehmet Akif İcke \\ Faculty of Political Sciences, Istanbul University, Istanbul, Turkey
}

\begin{abstract}
There is no simple answer to the question of why financial systems and firm financing vary from country to country. The most commonly used classification for the types of financial systems is the distinction of the bank-based and market-based financial system. In the studies conducted in economics and finance literature, it can be seen that these two systems cannot reveal an absolute superiority in terms of growth and prosperity in the countries. Our analysis state that in view of the future direction of the Turkish financial system, it may be thought that efforts to establish a "hybrid financial system" that can combine the bank-based financial system and the relatively superior aspects of the market-based financial system will be better.
\end{abstract}

Keywords: Bank-based, Market-based, Mixed-system, Financial System, Turkey

DOI: $10.7176 / \mathrm{EJBM} / 11-9-17$

Publication date:March $31^{\text {st }} 2019$

\section{Introduction}

Is there a "single" and best financial system when evaluating the financial structures of countries? Is there a formula that gives the best results for each country in terms of financial structure?Can it be said that this formula is suitable for every market, no matter what country you are in? The economists have long sought to answer the question of the best financial system in theory and practice. In the literature, classifications are made according to the differences between financial systems and there is a competition among these systems. Although the differences between financial systems have been sustaining, a convergence trend between systems is recognized by the impact of global financial integration.It is, therefore, no wonder that one of the most important debates in the social, economic and political fields at the end of the $20^{\text {th }}$ century was concentrated on the system problem for financial systems. This problem is usually tackled by discussions between American and Continental-European models.

The financial system is defined as a structure (markets, intermediaries and instruments) in which individuals, firms and governments provide funds for their activities and invest their savings. Within this structure, each institution has different roles and relative weights(Zogning, 2017, p.44).It is clear that an optimum financial structure, which can best fulfill the basic function of a financial system, will have characteristics specific to each country. There is no simple answer to the question of why financial systems and thus firm financing vary from country to country (Rybczynski, 1983, p. 9). At this point, it can be said that financial systems are not chosen as a result of an optimization process, but they evolve endogenously through the evolution in the historical process and respond effectively to the needs of a country's economic system (Schackmann-Fallis\&Schulz, 2015, p.228). The emergence of different types of financial systems has a history based on the beginning of The Industrial Revolution and, in some cases, even earlier.Factors that have a significant impact on the nature of the financial system include the level of growth of economies, the attitude of regulatory authorities, inflation experiences of countries, technological advances and, tax and other institutional arrangements. (Rybczynski, 1983, p. 9)

One of the preconditions for economies to use their current growth potential is that they have a sleek functioning financial system.In theory, it is stated that the effects of a well-functioning financial system on economic growth may occur especially in the field of efficiency in the capital distribution and technological progress (EuropäischeKommissionGeneraldirektionWirtschaft und Finanzen, 2001, pp. 139-140). Financial systems should contribute to the elimination of market failures with the least cost in terms of supporting macroeconomic growth dynamics. As a financial system fulfills risk management, combining and mobilizing of savings, resource allocation, and firm control, and making available the use of ease of payment, so the positive impact on economic growth will increase (Levine, 2003, p. 4; Hügle, 2001, p. 12).

The most commonly used classification for the types of financial systems is the distinction of the bank-based and market-based financial system. In this distinction, the relative importance of banks in the financing of nonfinancial firms, banks and capital markets in directing savings for individuals is taken as the basis (Passarge, 2010, p. 6). Generally, while Anglo-Saxon countries such as Canada, the USA, and the UK are considered as economies which have strong financial market dominance (market-based systems); Continental European countries and Japanese economies are considered to have a strong banking structure (Zogning, 2017, p.44). The process of disguising the financial system in a bank or market-based structure does not come into being by chance, and this structuring takes place depending on institutional factors. In the structuring of the financial system, the government is decisive by the regulations and laws it has made in this field. While evaluating in regionally, the basis of marketbased system evolution in the UK and the US is the result of special efforts. In these countries, especially firms 
that decided to invest in new ventures spontaneously were effective in creating the process. The system has emerged within the framework of venture capital, long-term funds and capital markets (Rybczynski, 1983, p.5).

Macro-economic savings in bank-based financial systems typically fall into the economic circulation in the form of bank loans. On the other hand, in the case of market-based financial systems, the most part of the company's financing is provided through capital markets and the banks are mostly expected to meet short-term financing needs of the company (Schwiete, 1998, p. 116).In the bank-based system, the most important role in intermediation between investors and lenders (savings holders) is played by conservative financial intermediaries primarily banks.However, in the market-based system, the capital market directly fulfills these intermediary activities (Kirchner, 2010, p. 428). In the literature, bank and market-based financial systems are generally compared to two typical systems (archetypal). These systems stand out as the sub-systems of the economically politically liberal and coordinated market economy (social market economy) (Handke, 2011, p. 71).

As a result of the convergence of financial systems with globalization, the net line between the bank and market-based financial systems is becoming indistinct. In fact, even if partly it should be accepted that all financial systems are "mixed systems" which have a certain but different degree of importance in investment and financing decisions of banks and stock exchanges.In this sense, it will be appropriate to understand the concepts of the bank and market-based financial system as a trend expression.

We have stated that the issue of which financial system is more effective than other systems, that has become an important problem of the economists for more than a hundred years, is controversial (Hügle, 2001, p. 80). The answer given to this question varies according to certain periods. One of the first contributions to the discussion was presented by Gerschenkron. According to Gerschenkron, the financial structures of these countries were influential in the development of a different economic development in the UK and Germany at the beginning of the $19^{\text {th }}$ and $20^{\text {th }}$ century. Therefore, the dominant opinion in Continental Europe in this period was that the financial systems in which the banks played a major role were more advantageous in terms of economic growth. Before World War I, rapid economic growth of Germany, which has a financial system where company financing is largely provided by commercial banks, is shown as proof of this (Gerschenkron, 1962, pp.14-15).In the 80s, the opinion, which was widespread at least in the US, was shaped by the direction that bank-based financial system which is underlying economic achievements of Japan and Germany (Hackethal\&Schmidt, 2000, p. 27). On the other hand, since the beginning of the 90s and most of today's opinions are shaped by the fact that the marketbased financial systems are superior for economic growth as in the US example (Allen \& Gale, 1995, p. 180).It is clear that the discussions will continue in different dimensions in the future.

In the first section of our study, the bank-based financial system is discussed and the general features, advantages, and disadvantages of the system are evaluated in detail.In this system, which is dominant in Continental Europe, it is stated that there is a large amount of short and long term bank loans among the financial instruments of the companies and banks carry out activities in all areas of banking services such as investment banking and securities and insurance activities besides deposit and credit services. The second section focuses on the market-based system features, which is another system compared. Contrary to the bank-based system, this system is interpreted as the systems in which the Anglo-American and Anglo-Saxon countries evolve, financing opportunities are mostly provided from capital markets and the more innovative and high-tech-oriented firms are concentrated. In the third section, the bank-based system and market-based systems are compared and their relative advantages are interpreted.From the standpoint of our subject, it is necessary to clarify the questions of whether a system is superior to the other, or whether it can be considered positive in terms of a country moving towards a bank or market-based financial system. In the last chapter, Turkey's financial system structure is discussed in the framework of all these analyses.In this context, the general characteristics of the markets are examined by taking into consideration the criteria of the distinction between bank-based and market-based systems. The structure of the Turkish financial system and the system in which it is closer is discussed.Also in Turkey which financial system gives better results along with which structure has been identified.

\section{Bank-Based Financial System}

According to Jackson and Vitols, financial intermediary operations in the bank-based financial systems are predominantly carried out through a banking system in which household savings are transferred to firms as loans. In bank-based financial systems the importance of capital markets is even lower. Bank-based financial systems are systems which have lower capital markets where relatively few firms being traded with lower stock market capitalization and liquidity as a rule (Jackson \&Vitols, 2001, p.2). Therefore, Berglöf et. al. say that, in the bankbased financial systems such as Germany and Japan, a large part of macroeconomic savings is steered to economic circulation in the form of long or short-term loans through the banking sector. Banks and companies have longterm relationships (Berglöf et. al. 1997, p. 99). The opinion of analysts is that since the rules in accounting and public disclosure are not sufficiently implemented, non-bank financial intermediaries are dependent on banks (Papenfuss, 1999, p. 38). In Continental Europe, a financial structure dominated by banks has developed over a time. Especially in Germany, banks are seen as the most important financial intermediaries for both corporate and 
individual customers (Vitols, 2004, pp.1-2).

It is possible to point the investment behaviors of households as a reason for capital markets to stay in the second position in the financing of companies in bank-based financial systems. In countries with a bank-based system, it is seen that there are generally public finance-backed pension systems. Therefore, there is no big need for households in these countries to follow private hedging strategies. Therefore, relative to the market-based systems, capital markets are lacking an important financing base in bank-based systems (Vitols, 2003a, pp. 176177). On the other hand, because of a wider public intervention in redistribution of revenue, households in the bank-based financial system may be subject to lower income distribution disparities than households in marketbased financial systems. Therefore, households in the bank-based system prefer less risky investments such as bank deposits. As can be predicted, an investor preference in this direction empowers the bank-based system again. For example, in Germany and Japan, where the income inequality is relatively low and solidaristic retirement is more important than the US, the bank-based system is highly supported (Vitols, 2001, p.18).

In the framework of Schumpeter's approach to the role of finance in the Innovation and growth process, it is seen that first Germany and then Austria shifted to the bank-based system as they develop. In this system, it is seen that banks fulfill an entrepreneurial function and provide financing of industrial holdings and participations in the short and long-term. The entrepreneurial role of the banks in this system results from the fact that this role has been given to them by the state, capital markets lack of an important position, the existence of state-supported institutional organizations and the power of money creation. (Rybczynski, 1983, p.15-16)

When we view regionally, it is seen that the bank-based financial system traditionally dominates in the EuroZone. The financing of non-financial firms in the Euro-Zone prominently consists of loans extended by banks. In 2012, approximately $31 \%$ of total liabilities of Euro-Zone companies were composed of bank loans while $85 \%$ of companies' external financing requirements were provided by the banking system. These ratios clearly figure out the weight of banking industry in the Euro-Zone financial structure. However, in the USA, which has a marketbased financial system, only $26 \%$ of companies' external financing requirements are composed of bank loans (Creditreform Rating AG, 2014, p. 6). However, in the Euro-Zone real sector financing, there are also estimates that the weight of the market-based financing will increase in the future (Creditreform Rating AG, 2014, p. 20).

When we approach the subject in terms of the financing structures of the companies, firstly the Pecking Order Hypothesis, which has emerged as a common denominator in both systems, is needed to be emphasized. In both financial systems, internal financing is at the top of the company financing tools, then external debt financing instruments are preferred in second and capital contribution ranks at third (Myers, 1984, p. 581). The bank-based system makes more use of bank loans in the financing of the company than the market-based system and provides a much lower share to bonds and equity financing (Emunds, 2003, p. 182).

It is possible to see that banks in economies dominated by the bank-based financial system are generally shaped according to the principles of "universal banking". In particular, as in the case of Continental-Europe, Universal Banking can operate in all areas of banking services such as deposit, credit services, investment banking, securities, and insurance activities. Therefore, in the universal banking system, banks have significant freedom in terms of geographically, the products they offer and the customer segment they have or functional strategic orientation (Bernet, 2003, p. 52).

The universal banking system offers an opportunity for banks to obtain equity shares in non-financial companies and to have voting rights in management. For this reason, banks can have a significant influence on strategic firm decisions (Vitols, 2003b, pp.3-4).

For example, in the German financial system, these banks may have control of equity participation and can hold collective voting rights on behalf of minority shareholders. In addition, banks may have an influence on these companies via acting as representatives of the supervisory board and also as lending institutions. Banks establish

long-term relationships with companies and they have a superior position due to the high level of this insider information (Boehmer, 1999, p. 9).

In terms of risk management, capital market instruments, especially futures markets, which may play a major role in the diversification of risks in this system, are underdeveloped. The basically vertical and intertemporal risk distribution model is formed. Risks are shared on a long-term basis and between banks and borrowers (Klein, 1998, p. 472). Since capital markets are less developed in the bank-based system, savings are invested in bank deposits and other fixed-income securities. The bank-based system provides superiority in intertemporal risk diversification in comparison with the market-based system (Hügle, 2001, pp. 89-90).

In terms of mobilization and consolidation of savings, the two systems do not have a significant effect on the size of saving rates. When merging the savings, it is seen that transaction and intermediation problems arise between depositors, banks, and investors due to the intermediation activities of banks in the bank-based system.

\section{Market-Based Financial System}

Financial intermediation activities in market-based financial systems are mostly met by the households' direct or indirect investments in securities issued by firms (Jackson \&Vitols, 2001, p.2). In this system, stocks and corporate 
bonds traded on the stock exchanges constitute the most basic financing sources of the companies (Passarge, 2010, p. 6). Therefore, a specific characteristic of market-based financial systems is the existence of highly liquid capital markets where a large number of firms are traded. In this system, capital markets come to the forefront with specialized financial institutions and money and capital market instruments that offer a wide range of options. US and UK are the most typical examples of the market-based financial system (Papenfuss, 1999, p. 42). The most important part of company financing is realized through capital markets. As can be estimated, the interest of small investors tends to prefer high-yielding investment options, while they do not aim to give priority to control the firms (Berglöf et. al., 1997, p.97). According to Demirguc-Kunt et. al., financial systems generally become marketbased over the economic development process. Moreover, the marginal effect of securities markets on economic activities also increases. Economic development will increase the development of securities markets more than bank development and thus the effect of banks will decrease (Demirguc-Kunt, Feyen\& Levine, 2011, p. 2)

Country's economic orientation and a number of social facts are taken into account while determining the financing system. In the market-based system, most of the financial strength is determined by the stock exchanges and the role of banks stays more limited. In this system, long-term relationships between banks and firms constitute more exceptions. On the other hand, the financing provided by banks is mostly limited with short-term loans and most of the financing of the company is realized through the capital market. In this system, the problem of representation among company managers and shareholders arises. In the Anglo-American system, it is accepted that danger of hostile takeover and thus changing the management of the firm is an important disciplinary mechanism (Schmidt \& Spindler, 2002, p.323). The market-based systems get banks to compete with other sources of finance. In many programs, on average, borrowers are directed to non-bank sources for financial sponsorship (Zogning, 2017, p.55).

Traditionally, since social security opportunities in the United States have been more limited than Continental Europe, private pension systems with no public funding support have developed. For this reason, the households in these countries have mainly interested in private hedging strategies and evaluated their savings in capital markets. On the other hand, entrepreneurs' need to obtain their financing requirements from the capital markets has become widespread as natural behavior (Vitols, 2001, pp. 21-22).

In the perspective of market-based financial system, due to the limited level of public intervention, in the redistribution of revenues, a relatively higher rate of income distribution inequality is observed. Therefore, in the market-based system, households with high-income levels may prefer investment instruments such as stocks and bonds which offer higher return and have less risk. On the other hand, it is seen that households with low incomes and low saving opportunities hold their savings mainly as cash or highly liquid deposits. An investor's behavior in this direction contributes to capital markets and therefore to the market-based system (Vitols, 2001, p.18)In these systems, the high importance of capital markets is the determinant of corporate governance structure and control of company management in these countries. Moreover, company management control is realized externally through markets (Passarge, 2010, p. 7; Vitols, 2003b, p. 5).

In the USA, which is an exemplary model of this system, it is observed that institutional investors have been trying to be more effective on the decisions of firms along with the flexibility of the legal ground after 1992. However, the impact of institutional investors on the decisions of a single firm has different specialties than Continental Europe. In the USA the average holding period of shares in the private pension funds managed actively does not exceed 1.9 years (Bolton \&Thadden, 1998, p. 4). Therefore, it is not possible to talk about the process of permanent influence carried out especially by those who provide great equities as in Continental Europe. It is seen that institutional investors in the USA behave like well-informed small investors.

Valickova, Havranek, and Horvath have also proved that the impact of stock exchanges on financial growth is more successful than the bank-based systems by analyzing 1334 estimates from 67 surveys. The financial structure was considered important for economic development and the contribution of the stock exchanges to the growth process was higher than that of other financial intermediaries. (Valickova, Havranek, \& Horvath, 2013, p. 25)

A distinctive feature of the market-based systems is the dominance of the "separate banking system" in these countries. A separate banking system, there is a functional distinction between investment banks engaged in securities transactions and commercial banks whose operations are limited with loan and deposit activity. Therefore, in this system, there is a banking system in which commercial banking activities and investment banking activities are separated by economically and legally (ZEW, 2013, p.1). In the market-based system with the effect of a separate banking system, the effects of banks on company management are very limited in terms of corporate governance compared to the bank-based system. This is due to the fact that banks have no or limited numbers of company shares. Therefore, banks act as intermediaries and not as company shareholders, and mainly tend to meet short-term financing requirements (Passarge, 2010, pp. 6-7).

In here, there is a mechanism in which the costs and risks associated with the financial intermediation are distributed horizontally to a large number of investors. In the market-based systems, the stock markets are thought to enable a more effective risk diversification. Therefore, it can be observed that market-based systems can offer 
much richer financial instruments that can be used in a diversification of risks compared to the bank-based systems (Klein, 1998, p. 470).

Specially developed, deep and liquid stock markets in the USA and futures and options markets play a very important role in the distribution of individual and intersectoral risks. The disadvantage of the market-based system can be shown to be insufficient to allow intertemporal risk balancing while taking into account the very volatile equity markets (Hügle, 2001, pp. 89-90).

The change in financial markets within the framework of securitization and innovation concepts both changed the financial structure and the role of banks significantly. This change encourages the transition from traditional deposit-based financing to more market-based funding sources. The loan markets have changed by decreasing the role of the traditionally called liquidity transformation which is realized by financial intermediaries. The expanding gap between loans and deposits have been also started to close by market-based financing approach. It is stated that securitization can increase the efficiency in the financial markets and spread the credit risk (Choi \& Park, 2018, p.328)

Up to this point, the main features of both financial systems have been exposed. In the following section, it will be tried to clarify the superiority and complementarity relations of these systems against each other.

\section{Discussion on Superiority of Financial Systems}

In the comparative analysis of financial systems, the lack of measurable magnitudes for the structure of financial systems and the interaction of various financial system functions within a system makes difficult for the empirical comparison of financial systems as a whole. Empirical studies in this area are generally made with a partial perspective covering one of the functions of the financial system and, therefore, cannot give a general idea about which system is superior in a holistic sense.

According to Allen et.al., there is a causal relationship between economic structure and financial structure. Even in the period of systemic crises, the structure of the real economy may affect the structure of the financial system. It is stated more probably having a bank-based system in asset-intensive sectors. When the financial system reaches the optimal structure depending on the characteristics of the real economy, any increase in the importance of fixed asset-intensive sectors will also lead to an increase in the role of banks. Countries which depend on knowledge and intangible assets sectors have a market-based financial system structure (Allen,Bartiloro\&Gu, 2018, p.21).

Fufa and Kim analyzed 64 countries with bank-based and market-based systems in their work on financial structures of high- and middle-income countries. While measuring stock market development, turnover ratio, traded value, and market capitalization were employed; for banking systems development bank variables such as credit, private credit, and liquid liabilities were used. In their study for middle-income countries, it is revealed that the size of loans to the private sector and the liquidity of the stock market have strong positive effects on the economic growth of middle-income countries. In the analysis for the countries with high-income levels, only the stock market liquidity has positive and strong effects. It is also said that bank loans triggered the growth for both middle and high -income countries. In countries with high-income levels in the European continent, the liquidity of the stock market does not appear as a strong determinant of growth. On the other hand, for countries in the highincome group outside Europe, stock exchange liquidity has proven to be a marginal effect. In general, it is concluded that banks and stock exchanges have different roles for economic growth. However, as a general conclusion, financial development and economic growth exhibit different connections for groups in various stages of economic development (Fufa\& Kim, 2018, pp. 505, 517).

Levine states that the financial structure does not have a significant relationship with economic growth. While the bank-based system indicates a negative relationship between growth and financial structure measures; a positive relationship is stated in the market-based system. According to Levine, the bank-based system is superior to the market-based system in order to mobilize savings in the early stages of development and in the weak institutional environment, to allocate capital and to implement institutional control. However, Levine asserts that the market-based system includes a structure that promotes innovation and long-term growth. Finally, he argued that distinguishing countries with their financial structures cannot help to explain the differences between countries in terms of long-term economic performance (Levine, 2002, pp. 414, 423).

In the studies conducted in the $19^{\text {th }}$ century, for long-term economic growth while it is stated that the bankbased system which is one of the two financial systems offers more advantageous in the early stages of economic development, in mobilizing savings in the weak institutional environment, in determining good investments and in the establishment of a sound institutional control environment; in the market-based system markets have some advantages to reduce the natural deficiencies of banks and increase economic growth. In some studies conducted at the beginning of the 1990s [Levine (2002), La Porta $(1998,2002)$ ], it was stated that distinguishing countries with their financial structure could not help explain the long-term economic performance. The financial structure is not closely to related with the economic growth either in the bank-based system and market-based system. Instead, there are a large number of authors who think that distinguishing countries according to general levels of 
financial development reveals the economic growth differences between countries. In particular, the legal rights of foreign investors and the effectiveness of the legal system in the application of these rights are argued to have a stronger relationship with long-term growth. On the other hand, some economists argue that such relations on economic growth do not need to be stable and may change over time [Boyd \& Smith $(1996,1998)$, Rajan\&Zingales (1998), Boot \&Thakor (1997), Perotti, \& von Thadden (2003)]. In the cross-country analysis of Lee's study, the stock markets in the United States, the UK and Japan played an important role in the financing of economic growth; In Germany, France, and Korea, the bank-based system has an impact on growth. When more detailed analyses are performed, it is seen that the bank-based system plays an important role for all countries in the first years of growth. In addition, while in all countries except the USA the mentioned economic systems have complementary effects; this effect appears itself as a substitution in the US. For Korea, strong pieces of evidences have been found that economic growth leads to the development of the financial system. Especially in recent years in Japan, it is stated that the stock markets played a more effective role in economic growth than in the banking sector (Lee, 2010, pp.174, 195-196).

The bank-based systems have an advantage in terms of providing a long-term stable financial framework for companies, while the market-based systems have a more variable structure. However, one of the relative advantages of market-based systems is their creating ability to transfer funds to new companies in innovative industries more quickly (Vitols, 2001, p.1).

The distinction between market-based and bank-based financial systems can be seen both in the structure of corporate liabilities and in the structure of household assets. While securitized debts in both the US and the UK constitute the majority of corporate debt (61\% and 67\%, respectively); In Germany and Japan respectively accounted for $21 \%$ and $15 \%$. Similarly, there are large differences in the structure of household assets. In the United States and the United Kingdom, money and bank accounts are $21 \%$ and $25 \%$ of total household assets, respectively; In Germany and Japan, these are 43\% and 62\% respectively. (Vitols, 2001, pp.3-4)

In view of the availability of payment facilities, there is no significant distinction between the two financial systems, considering only the traditional types of payment instruments. However, when we accept derivative instruments as payment instruments, the relative superiority of the market-based system is revealed.The reason for this is that the market-based system has advanced diversified, innovative and tradable financial instruments, and also liquid derivatives markets(Hügle, 2001, p. 97).

Although a substitution relationship may arise between to the banking and stock exchange services which also related with the development level of the financial system, there is no denying that a certain complementarity relationship exists. In this respect, it is seen that the stock exchanges have a comparative advantage in the financing of the dynamic sectors in the protection of banks against intertemporal risks. Considering the practice, it is seen that the demands of introducing some elements of the bank-based system have been realized in the countries having a market-based system; while in bank-based systems some basic elements of the market-based system have also been implemented by strengthening the capital markets.Adoption of the system in 1999 where the banks, which had previously been banned before, were able to perform banking transactions and stock exchange transactions under the same roof, and the flexibilization of distinguishing the banking and the insurance transactions can be given as an example for this process. On the other hand, in continental Europe, as a result of the deregulation and restructuring process accelerated with the financial integration and the transition to the Euro in recent years, it is observed that the depth of capital markets has increased.In addition, it is observed that venture capital markets are successfully implemented with the effect of the "Risk Capital Action Plan" in many EU countries.In particular, the successful establishment of the NeueMarkt, where the new economy companies were traded in Germany in 1997, can be cited as a sign of the direction towards the market-based system (Hügle, 2001, p. 103).

Unlike direct-capital-supported sectors, bank-financed sectors tend to grow more slowly in financially highdeveloped countries. Contrary to developed countries, sectors that are dependent on banks in low GDP countries grow faster as the banking system develops. Market-based systems are predicted to be more likely to dominate at the times of major industrial change, while bank-based systems may have an advantage when other institutions in an economy are underdeveloped. Rajan and Zingales indicate that for sectors that accelerate growth in the world, the introduction of a hybrid model can yield the best results rather than to prefer a bank-based or market-based system. However, it should be noted that some of the best features of both systems may be lost within the hybrid structure (Rajan\&Zingales, 2001, pp.480-481).

In industrialized countries, the emergence of hybrid structures, which increasingly combine the basic elements of the bank and market-based system, can be regarded as a sign of the convergence of financial systems.After the $1970 \mathrm{~s}$, deregulation practices in the financial sector, globalization, the increase in international competition, led to a decrease in the financial system differences in between the industrialized countries. One reason for the decrease of the differences between financial systems is that firms can acquire in the capital they need from one of the financial centers in any country on the world without serious difficulties.It is thought that the current differences between financial systems are shaped according to the historical, cultural and political structure in which the national legal regulation processes in these countries are formed (Prowse, 1996, p.12). 
As a result, it is possible that the elements of both systems can be united in a hybrid system, and it is already known that such a tendency exists in the industrialized countries. Therefore, the fact that the financial systems are converged must not be understood as the loss of the importance of the banks in the definitely banking-based systems. On the contrary, in such a case, in the framework of the thesis that the systems will complement each other the importance of financing from capital market will increase; and at the same time, the quality of the banking and stock exchange services will increase. This means that the development of stock markets in time will not result in a reduction in banking activities. Stock markets and banking activities do not substitute each other but are in a complementary relationship that contributes to the mutual development of each other (Demirguc-Kunt\& Levine, 1996, p.313).

In terms of allocation of macroeconomic resources, there are specific advantages and disadvantages between banking and capital markets. According to Allen and Gale, developed financial markets both have positive effects on the size of production factors and help to use existing factors more effectively. In particular, today where technological progress is accelerating, the effectively structured finance sector can offer significant opportunities for technological regeneration in capital accumulation. In this way, there are opportunities for countries to turn technological advances into higher economic growth rates (Allen \& Gale, 1999, p.82). In Allen and Gale's study, it is stated that financial markets in the US are able to offer many opportunities for individual investors to diversify their risks and secure their current positions. In this respect, the United States capital market is exemplary in terms of the richness for the creation of venture capital for newly established companies and especially the creation of new workplaces. When we look at the issue in terms of venture capital, if we exclude efficient capital markets, it is seen that a market-based financial system is superior to the banking-based system (Allen \&Gale, 2001, p.11).

Accordingly, in the case that there are relatively different opinions on the profitability of the project to be financed and the cost of collecting information is low, financing from capital markets could be more favorable than banks. They state that financing from banks is more suitable for traditional sectors (agriculture) (Allen \&Gale, 1995, p.205). This result implies that the brokerage services offered by banks and exchanges are not the competitor to each other, but complementary to each other.

As a result, in practice, it is seen that an economy dominated by small and medium-sized enterprises, which use physical capital intensively in the production process, provides an advantage over loan finance through the bank-based financial system. On the other hand, an economy based on technological innovations, which is mostly dominated by large firms, has more advantages in the market-based finance system. Today, one of the most important superior aspects of the market-based systems is the mobilization of venture capital for innovations (Schackmann-Fallis\&Schulz, 2015, p. 227). Therefore, while evaluating which financial system is superior, instead of making a general evaluation, it would be better to make an evaluation which is specific to the existing economic structure of that country. If it is desired to strengthen the SME sector in the real industry as the aim of economic policy, accordingly it would be appropriate to construct a bank-based financial system (SchackmannFallis\& Schulz, 2015, p. 228).

Table 1. Distinguishing Features of Financial Systems

\begin{tabular}{|l|c|c|}
\hline & $\begin{array}{c}\text { Bank-Based } \\
\text { Financial System }\end{array}$ & $\begin{array}{c}\text { Market-Based } \\
\text { Financial System }\end{array}$ \\
\hline The share of bank loans in corporate finance & High & Low \\
\hline $\begin{array}{l}\text { The share of commercial volumes of banks in } \\
\text { gross national product }\end{array}$ & High & High \\
\hline $\begin{array}{l}\text { The share of the market value of domestic } \\
\text { companies' share capital in the gross national } \\
\text { product }\end{array}$ & Low & High \\
\hline Number of listed companies & Low & High \\
\hline Participation of households in capital companies & Low & Low \\
\hline Participation of banks to capital companies & Available & Liquid \\
\hline $\begin{array}{l}\text { The Concentration of the owners and the } \\
\text { investors }\end{array}$ & High & Rich \\
\hline Futures and Options markets & Non-liquid & High \\
\hline Leverage of firms & Limited & Controlling firms by \\
\hline Information available from capital companies & \begin{tabular}{c} 
Long term bank relations \\
\hline Firm control
\end{tabular} & $\begin{array}{l}\text { (Participation to capital companies } \\
\text { through banks }\end{array}$ \\
\hline
\end{tabular}

Source: Wolfgang Hügle, Finazsysteme, Wirtschaftliches Wachstum und die Rolle des Staates: Eine Funktionaler Ansatz unter Berücksichtigung der Reformerfahrung Lateinamerikanischer Länder, Dissertation, Universität zu Köln, 2001, p. 77. 
In Table 1, the most important differences between the bank-based finance system and the market-based financial system are summarized within the framework of various elements.

\section{Turkey: Bank-Based or Market-Based System}

According to the World Bank's data, the economic and social development performance of the Turkish economy has been impressive up to the last year. It is stated that from the beginning of the 2000s until 2017, significant developments have been achieved in the field of foreign trade and finance, great importance is given to harmonization with EU standards and that there are successful initiatives to reduce poverty rates. However, according to World Bank's analysis which estimates that the growth rate of $7.4 \%$ in 2017 will reduce to $3.7 \%$ in 2018 and to $2.3 \%$ in 2019 indicates that some policy changes are needed. When look at the data on GDP per capita, Turkey is required to increase the level of financial development to perform the necessary structural transformation for achieving the sustainable development goal and escaping from middle income trap that seem to be caught. Our primary objective in accordance with our subject, to determine whether Turkey prefer the bank-based or marketbased financial system and, moreover, to reveal that again in the financial system context which structural alterations make advantages to overcome the problems mentioned before.

As stated in the previous sections, in the literature, different criteria are used in the separation of the bankbased and market-based systems. In this study, firstly when we analyze elements which are taken as basis for bankbased system for Turkey and other compared countries, assets of banking sector / GDP data as well as domestic credit to the private sector by banks data are also evaluated. Among the main indicators of the market-based system, we include the rates of market capitalization of listed domestic companies (\% GDP), stock traded, total value (\% of GDP), and number of listed companies in our study. The data for these criteria are shown in the following tables. While determining the comparative countries included in our evaluations, it has been paid attention to include bank-based financial system and market-based financial system representatives. In this context, Australia, the US and the UK are expressed as market-based system representatives; Germany and France were selected as representatives of the bank-based financial system. Developing countries such as Argentina, Hungary and Russian Federation which has similar financial specialties are also included.

The first criteria we will consider is the ratio of assets of banking sector/GDP in Table 2 Considering this rate, while the ratio is lower for Turkey comparing with Germany and France which have the bank-based financial systems; it appears to be closer to the countries which has the market-based financial systems such as the US. Just by looking at this rate, it will not be correct to classify Turkey as a market-based system. The reasons for low rate in Turkey's than other countries which have the bank-based financial system can be explained by falling behind of developing countries in terms of banking system and the level of financial development.

Table 2. Assets of Banking Sector/GDP: 2010-2016

\begin{tabular}{|l|r|r|r|r|r|r|r|r|c|}
\hline Years & Argentina & $\begin{array}{c}\text { Australi } \\
\mathbf{a}\end{array}$ & France & $\begin{array}{c}\text { German } \\
\mathbf{y}\end{array}$ & Hungary & Turkey & $\begin{array}{c}\text { Russia } \\
\text { Fed. }\end{array}$ & UK & US \\
\hline $\mathbf{2 0 1 0}$ & 18.68 & 123.80 & 112.25 & 112.38 & 76.43 & 60.60 & 41.68 & 187.62 & 60.57 \\
\hline $\mathbf{2 0 1 1}$ & 18.62 & 121.96 & 112.32 & 106.57 & 75.07 & 60.13 & 42.15 & 177.85 & 59.41 \\
\hline $\mathbf{2 0 1 2}$ & 19.56 & 109.19 & 113.79 & 104.27 & 71.71 & 62.16 & 44.99 & 165.47 & 58.39 \\
\hline $\mathbf{2 0 1 3}$ & 19.56 & 124.86 & 114.06 & 102.35 & 63.71 & 64.71 & 49.50 & 154.50 & 58.39 \\
\hline $\mathbf{2 0 1 4}$ & 18.98 & 127.96 & 113.02 & 98.81 & 59.27 & 69.47 & 53.70 & 141.32 & 58.68 \\
\hline $\mathbf{2 0 1 5}$ & 20.15 & 135.98 & 111.79 & 95.94 & 56.61 & 70.62 & 61.10 & 132.98 & 59.93 \\
\hline $\mathbf{2 0 1 6}$ & 19.66 & 140.99 & 112.46 & 93.41 & 55.11 & 73.27 & 61.13 & 130.48 & 62.67 \\
\hline
\end{tabular}

Source: Adapted from https://www.theglobaleconomy.com/rankings/bank assets GDP/

Domestic credit to private sector by banks (\% of GDP) data is exhibited in Table 3looking at this ratio, Turkey has higher rate compared to the market-based systems and shows the bank-based financial system features more. Since 2012, as Turkey's economy grows, the upward trend in this ratio is support for our interpretations. Rising of this rate in the US and the downward trend in Germany for this rate supports the interpretation of the fact that the two systems tend to converge. 
Table 3. Domestic Credit to Private Sector by Banks (\%of GDP)

\begin{tabular}{|l|r|r|r|r|r|r|}
\hline & $\mathbf{2 0 1 2}$ & $\mathbf{2 0 1 3}$ & $\mathbf{2 0 1 4}$ & $\mathbf{2 0 1 5}$ & $\mathbf{2 0 1 6}$ & $\mathbf{2 0 1 7}$ \\
\hline Argentina & 14,69 & 15,18 & 13,46 & 14,08 & 13,29 & 15,53 \\
\hline Australia & 121,50 & 124,98 & 128,73 & 136,59 & 142,52 & 140,90 \\
\hline Canada & $\mathrm{N} / \mathrm{A}$ & $\mathrm{N} / \mathrm{A}$ & $\mathrm{N} / \mathrm{A}$ & $\mathrm{N} / \mathrm{A}$ & $\mathrm{N} / \mathrm{A}$ & $\mathrm{N} / \mathrm{A}$ \\
\hline France & 96,54 & 96,01 & 94,08 & 95,08 & 96,90 & 99,75 \\
\hline Germany & 83,41 & 81,66 & 79,16 & 77,67 & 77,07 & 77,23 \\
\hline Hungary & 50,62 & 46,21 & 42,89 & 35,73 & 34,12 & 33,32 \\
\hline Russian Fed. & 43,87 & 47,92 & 53,47 & 56,43 & 53,37 & 52,68 \\
\hline Turkey & 49,10 & 57,15 & 59,94 & 62,93 & 65,73 & 66,51 \\
\hline UK & 163,35 & 151,99 & 137,39 & 137,74 & 134,07 & 135,87 \\
\hline US & 49,52 & 49,18 & 50,08 & 51,59 & 52,99 & $\mathrm{~N} / \mathrm{A}$ \\
\hline
\end{tabular}

Source: Adapted from https://www.theglobaleconomy.com/rankings/domestic credit private sector/

In our study for the market-based system analysis, we employ the market capitalization of listed domestic companies (\% GDP), stock traded, total value, (\% of GDP) and number of listed companies' ratios among main indicators of this system.

Table 4.Market Capitalization of Listed Domestic Companies (\%GDP)

\begin{tabular}{|l|r|r|r|r|r|r|}
\hline & $\mathbf{2 0 1 2}$ & $\mathbf{2 0 1 3}$ & $\mathbf{2 0 1 4}$ & $\mathbf{2 0 1 5}$ & $\mathbf{2 0 1 6}$ & $\mathbf{2 0 1 7}$ \\
\hline Argentina & 6.3 & 9.6 & 11.4 & 9.4 & 11.5 & 17.1 \\
\hline Australia & 89.9 & 86.8 & 88.0 & 88.0 & 105.0 & 114.0 \\
\hline Canada & 112.9 & 114.7 & 116.5 & 102.2 & 129.8 & 143.2 \\
\hline France & 67.4 & 81.9 & 73.1 & 85.6 & 87.6 & 106.5 \\
\hline Germany & 41.9 & 51.6 & 44.7 & 50.8 & 49.3 & 61.5 \\
\hline Hungary & 16.2 & 14.6 & 10.4 & 14.4 & 17.9 & 22.7 \\
\hline Russian Fed. & 37.3 & 33.5 & 18.7 & 28.7 & 48.4 & 39.5 \\
\hline Turkey & 36.1 & 20.6 & 23.5 & 22.0 & 19.9 & 26.7 \\
\hline US & 115.6 & 144.0 & 151.1 & 138.3 & 146.9 & 165.7 \\
\hline
\end{tabular}

Source: Adapted from:

https://databank.worldbank.org/data/reports.aspx? source=2\&series=CM.MKT.LCAP.GD.ZS

The data in the Table 4 shows the ratio of all companies listed in the country to the GDP of that country. The data shows that the US, Canada and Australia have higher values than Germany and France which have the bankbased system. This lower ratio can be attributed to the fact that the Turkish finance system lags behind the developed countries. However, this lower rate may be interpreted that Turkey is closer to the bank-based financial system.

Table 5.Stock Traded, Total Value, (\%of GDP)

\begin{tabular}{|l|r|r|r|r|r|r|}
\hline & $\mathbf{2 0 1 2}$ & $\mathbf{2 0 1 3}$ & $\mathbf{2 0 1 4}$ & $\mathbf{2 0 1 5}$ & $\mathbf{2 0 1 6}$ & $\mathbf{2 0 1 7}$ \\
\hline Argentina & 0.3 & 0.4 & 0.7 & 0.5 & 0.8 & 1.0 \\
\hline Australia & 5.8 & 6.2 & 6.5 & 8.3 & 6.8 & 9.6 \\
\hline Canada & 73.9 & 71.8 & 74.7 & 70.3 & 75.1 & 77.4 \\
\hline France & 40.0 & 39.3 & 41.0 & $\mathrm{~N} / \mathrm{A}$ & $\mathrm{N} / \mathrm{A}$ & $\mathrm{N} / \mathrm{A}$ \\
\hline Germany & 35.3 & 35.0 & 32.6 & 42.8 & 32.3 & 42.4 \\
\hline Hungary & 8.6 & 8.0 & 5.1 & 6.1 & 6.2 & 7.5 \\
\hline Russian Fed. & 15.4 & 10.3 & 7.8 & 8.6 & 10.9 & 9.2 \\
\hline Turkey & 41.1 & 39.4 & 39.6 & 40.7 & 32.6 & 44.3 \\
\hline US & 200.2 & 199.2 & 223.6 & 228.5 & 225.9 & 205.2 \\
\hline
\end{tabular}

Source: Adapted

from:https://databank.worldbank.org/data/reports.aspx?source=2\&series=CM.MKT.TRAD.GD.ZS

The Table 5 shows the ratio of the securities traded in the stock exchange to the GDP of the countries. In this context, it is seen that the US performs the best and followed by Canada. The fact that the data of Germany and France are also far behind the US reveals the difference between the market-based system and the bank-based system. This data strengthens our idea that Turkey has the bank-based financial system. The ratio which is closer to Germany and remaining higher than other developing countries in the table shows that Turkey's stock exchange market is more active compared to those countries. 
Table 6. Number of Listed Companies

\section{Source:Adapted}

\begin{tabular}{|l|r|r|r|r|r|r|}
\hline & $\mathbf{2 0 1 2}$ & $\mathbf{2 0 1 3}$ & $\mathbf{2 0 1 4}$ & $\mathbf{2 0 1 5}$ & $\mathbf{2 0 1 6}$ & $\mathbf{2 0 1 7}$ \\
\hline Argentina & 101 & 97 & 95 & 93 & 93 & 96 \\
\hline Australia & 1.959 & 1.955 & 1.967 & 1.989 & 1.969 & 2.013 \\
\hline Canada & 4.030 & 3.810 & 3.948 & 3799 & 3.368 & 3.278 \\
\hline France & 562 & 500 & 495 & 490 & 485 & 465 \\
\hline Germany & 665 & 639 & 595 & 555 & 531 & 450 \\
\hline Hungary & 51 & 50 & 48 & 45 & 43 & 41 \\
\hline Russian Fed. & 292 & 261 & 254 & 251 & 242 & 230 \\
\hline Turkey & 242 & 253 & 226 & 392 & 380 & 374 \\
\hline UK & 1.879 & 1.857 & 1.858 & $\mathrm{~N} / \mathrm{A}$ & $\mathrm{N} / \mathrm{A}$ & $\mathrm{N} / \mathrm{A}$ \\
\hline US & 4.102 & 4.180 & 4.369 & 4.381 & 4.331 & 4.336 \\
\hline
\end{tabular}

from:https://data.worldbank.org/indicator/CM.MKT.LDOM.NO?end=2017\&locations=US\&start=2012

The table above shows the number of listed company data of 10 countries. Accordingly, the difference between the number of listed companies in developed countries such as Australia, Canada, the US and the UK and in the others is clearly visible. In this distinction, the US takes the first place and followed by Canada, Australia and England. The figures in Turkey dramatically come behind the market-based system countries. When this data is evaluated, Turkey is seen still stays in the side of the bank-based system. As a result, it is possible to say that in respect to all of the criteria Turkey has a bank-based financial system similar with the continental European countries that Turkey has closer economic relations with them even in different levels. In support of our findings, when we look over firms using bank credit to finance investment, (\% of all firms) this ratio is $30.26 \%$ in 2017 and it is $26.16 \%$ in worldwide. In the World Bank statistics this ratio is available for Turkey in 2013 and it is explained as $44.2 \%$. The ratio is above both the World and the OECD average. As result it can be said on these criteria that the financial system in Turkey seem to be closer to the bank-based system.

In the literature, when we review the studies which include Turkish financial system it is seen that Turkish financial system is classified in the bank-based financial system with the exception of some studies.

Firstly, the ICSA Report (2015) reveals that the Turkish financial system has a bank-based structure. On the other hand, it is stated that there is a need for further development in order to pass to the market-based structure. Market capitalization to GDP, loan to GDP ratios, total savings amounts, equities and fixed income instruments are used as evidence for this assessment. In addition, in their evaluation for the 2004-2013 period, the decline in the savings rate in Turkey is underlined and problem on the accumulation of capital is pointed out.

Aggarwal and Goodell (2016) concluded that Turkey has a market-based structure by evaluating the stockmarket capitalization to domestic assets ratio in their study for the period 1996-2003.

Aivazian and Booth evaluate the financial systems of countries according to stock exchange and banking system development, corporate governance, protection of investors and creditors, accounting standards, legal system and level of corruption. According to their classification in the framework of criteria, they assess Turkey's financial system outlook as a bank-based system because of weakness in development of financial and capital markets criteria and strong applications creditor rights (Aivazian\& Booth, 2003, pp. 373, 375).

Akdoğan et. al., stating that more than $90 \%$ of the financial sector assets are managed by banks, they evaluate the Turkish financial system in a bank-based structure compared to many western countries (Akdoğan, Gülhan\&Aktaş, 2017, p. 182).

Aydin et. al. proportion of bank loans in the corporate sector liabilities in Turkey is closer to the average of developed countries (G7). However, it is stated that since there are representatives of both the market-based (e.g. the USA and the UK) and the bank-based (e.g. Germany) financial systems in G7 making such an inference is not all that right. According to their findings, the Turkish financial system seems as a "bank-based" system rather than a "market-based" system (Aydın et. al., 2006, p.11).

It is beneficial to touch upon the study of Demirguç-Kunt and Levine, which has relatively earlier assessments. Although it is stated that financially underdeveloped economies are expected to be in a bank-based structure, it is pointed out that many variables are effective in this distinction. In this respect, it is seen that countries such as Chile, Mexico, Turkey and Philippines can be classified as a market-based system. One reason of that is the significant developments in the stock markets of these countries after the second half of the 1980s. In addition, in most of these countries, including from Turkey, that the low level of development of the banking system are also taken care of. According to bank credit versus trading measure, Turkey, Mexico and Brazil could be classified as a market-based system; however, they emphasize that these countries have lower total valued traded / GDP ratio than it should be (Demirguç-Kunt\& Levine,1999, pp.18, 20).

Lizethe and Steven, on the other hand, analyze 48 countries in the period 1980-2014. According to various criteria in their analysis, they classify countries within the framework of financial systems. According to the 
structure activity indicator, it is stated that the US, Pakistan and Turkey are engaged in stock market activities rather than banking activities. While talking about a whole the market-based system for the US, they indicate that the case for a few countries such as Turkey is being sourced from low credit rating rather than the higher total value of equity shares not traded (Lizethe\& Steven, 2018, p.12).

As we have already explained, in empirical studies, none of the bank-based and market-based financial systems is absolutely superior to the other system is out of question. Therefore, it can be seen that there is no general conclusion that a financial system has significantly increased economic growth compared to the other system. Therefore, it is seen that the studies in the literature mainly focus on the analysis of the relationship between financial development and economic growth. In the end, while discussing which financial system is superior, it would be more accurate to make an assessment based on the economic structure of that country instead of making a general analysis (Schackmann-Fallis\& Schulz, 2015, p.228).

In the historical process, it is seen that national financial systems follow a different development line in the framework of their own economic and legal conditions and have different structure (Schackmann-Fallis\& Schulz, 2015, p.227).An industrial structure with many medium-sized firms that tend to use physical capital intensively in production can be used more efficiently by a bank-based financial structure. Therefore, if it is desired to strengthen the SME sector in the real economy as the target of economic policy, it would be appropriate to construct a bankbased financial system (Schackmann-Fallis\& Schulz, 2015, p.228). Such firms can easily access to low volatility returns and physical capital. On the other hand, the market-based financial structure stands out as a more suitable system for some large firms that use qualified human capital and other intangible capital in production and economies based on high specification technological innovations. (Pagano et. al., 2014, p.23)

After reaching the conclusion that Turkey has a bank- based financial system, study of Altıntaş and Ayrıçay shows whether there is a complementary or a substitutional relationship between money and capital markets which is another topic of discussion in the literature. According to them, there is a complementary relationship between money and capital markets in Turkey. It is stated that funds are supplied by the financial intermediaries, thus the growth is positively influenced, in addition increase in positive interest rates as well as in financial savings volume create financial depth increase effect, which can stimulate the growth by increasing the capital efficiency (Altıntaş\&Ayrıçay, 2010, p. 87). As a result, both in terms of Turkey and global it will not be wrong to say that complementary relationship between global banking and capital markets outweigh.

Finally, it will be beneficial to add the following finding to our assessment. According to the bank-based system, the financial system has a weak institutional structure in the early stages of the economy. The bank-based system should be seen as a more useful system for emerging economies with the provision of savings, allocation of capital and better utilization of institutional capital than a market-based system (Gezer, 2018, p. 97). It is also possible to make the same determination for Turkish economy. In this context, having a bank-based financial system will be an appropriate structure for Turkey in terms of financing economic growth.

Middle-income countries are stuck in this middle-income level if they cannot bring their growth strategies from resource-driven to productivity-driven. Middle-income countries are mostly squeezed between low-income labor-intensive industries and high-income capital-intensive industries. It is difficult for both to compete along with increasing wages, price, innovation and technology. Developing countries can get rid of low-income levels by increasing their growth rates. However, it will be inevitable for them to experience some new difficulties in converting their import-oriented investments into domestic innovations (Gezer, 2018, pp. 97, 107). For a long time remaining of the level of GDP per capita in Turkey at around \$10,000 suggests that caught to the middle-income trap. In our opinion, to overcome middle income trap, Turkey needs to develop capital markets rather than banking system in terms of realizing above-mentioned structural reforms and especially in financing innovation and venture capital. This means that Turkey requires converting to the market-based systems. Since there is a complementarity between the two systems, it can be predicted that the level of financial development will increase. On the other hand, development of capital market would be more beneficial to increase savings rate in Turkey's economy where is savings deficit, as well as to transfer the cushion capital to the financial market and direct it to the financing of the growth. It is a great benefit that ethical funds (in general, all socially responsible investment instruments) are encouraged and offered to the preference of conservatives in order to gain cushion capital especially held by conservatives with interest sensitivity that are not transferred to the financial sector. Such a financial transformation will accelerate the process of rising Turkey to the developed countries league and exiting the middle-income trap.

However, it would not be correct to see the transformation of an economy from a bank-based system into a market-based system as a short time and easy process. For such a transformation, there will have to be enough supplier and demander economic units in that economy. When we look at the existing external financing components of the Eurozone in the last decade, it is not possible to see such capital supply and demand components (Bechtold, 2014, p.18). It is possible to make same comment for Turkish economy. The most important partner of Turkey which in the EU accession process and has deal of customs union with EU, is seen as Europe in terms of economic relations. In this respect, it should be seen natural for Turkey being similar to continental-European 
countries with bank-based financial system and being closer to a structure dominated by banks.

In order to strengthen this interpretation, it is seen that the ratio of bank balance sheet volumes to fund managements balance sheet volumes (pension funds, insurance, investment and hedge funds) in the European financial system is lower than market-based systems. In addition, on the corporate investor side, it is possible to say that banks and insurance companies are dominant in Continental Europe. As in the case of the US, while large private pension and hedge funds dominate the capital market, private equity companies are not prevalent. While the ratio of private pension funds to GDP is roughly 75\%; the same ratio is around 5\% in countries such as Germany and France (Bechtold, 2014, p.18). It is seen that Similar to the Continental Europe, ratio of bank balance sheet volumes to fund managements balance sheet volumes in Turkey is lower than the market-based systems and OECD averages, and banks and insurance companies dominate institutional investors area.

From the perspective of individual investor behavior, monetary accumulations in Europe is traditionally concentrated in the banking system. However, it is difficult to argue that investments in equities and funds have reached a significant level and are on an upward trend (Bechtold, 2014, p.18). The same interpretation is also possible for Turkey. Even if we take into consideration the fact that Turkish capital markets are not as developed as the European capital markets, the tendency of Turkish individual investors directing to the banking system will be more dominant.

In terms of the demand side of financing instruments, we view an economic structure in which the SMEs are more weighted in the Eurozone. In addition, we often encounter structure of family companies, including large firms. In such companies, it is pointed out that the demand for going public via organized capital markets or even if the public offering is realized the free float rate remains limited (Bechtold, 2014, pp. 18-19). Turkey's economy also exhibits similar structural features. Both in terms of publicly traded companies and free float rates as well as Turkey lags behind the countries which have a market-based financial systems, even lags behind ContinentalEuropean countries. In light of the above, it can be stated that it is a difficult long-term process transformation of Turkey's the bank-based system to the market-based financial system.

\section{Conclusion}

Within the framework of criteria that we used in our study, we can say that Turkey has a bank-based financial system. In addition, our opinion is supported in a number of studies made in this direction related to Turkey. In the studies conducted in economics and finance literature, it can be seen that these two systems cannot reveal an absolute superiority in terms of growth and prosperity in the countries. Starting from these findings, in a straight logic, it can be thought that Turkey's having a bank-based financial system would not make a difference. However, instead of discussing the absolute superiority of both systems, it would be more meaningful to make an assessment specific to each country's own economic structure.

Theoretically and empirically, neither the bank-based or market-based financial systems do not have an absolute superiority to others. Only relative advantages and disadvantages arise in terms of the specific functions of the two systems. Therefore, we believe that the theoretical basis of the claim that the Anglo-American type market-based financial system is superior and the efforts of importing all the elements of that system into continent European countries or developing countries without considering economic differences are not very robust.

In view of the future direction of the Turkish financial system, it may be thought that efforts to establish a "hybrid financial system" that can combine the bank-based financial system and the relatively superior aspects of the market-based financial system will be better. For Turkey, to survive in global competition and the way to achieve the necessary structural transformation should be expected to pass through maintaining well-functioning aspects of the bank-based system and the creation of advanced capital markets. In such a system, different financial intermediaries will be able to act in competition with each other and be able to enrich their activities in accordance with the needs of the market.

Given that there is a complementary relationship, creating stable banking system and well-functioning money and capital markets will enable both types of financial intermediation develop at the same time. In this respect, both for the establishment of a stable banking sector in Turkey as well as well-functioning capital markets, it will be necessary to build the institutional conditions. The quality of the institutional infrastructure can be considered an indispensable condition for the healthy development of such a financial system. Thus, an optimum financial system structure will be possible.

It will not be realistic to expect the Turkish financial system, which has become its current state in many years, become a market-based system with all its elements at once. Turkey who wishes to develop own capital markets, need to gain more ground, especially, in terms of complying with new financial instruments, public disclosure and in the field of protection of small investors.

Given the current structure of Turkish financial markets, it is difficult to say that the country is able to fully utilize its economic potential. We believe that Turkey needs developed capital markets to use its own potential. Nowadays, when considering gradually intensified global competition, Turkey requires dynamic markets to encourage innovation especially in the sense of Schumpeterian, and to provide opportunities to advanced 
technology producing sectors and startup firms that they can finance themselves more effectively. The marketbased system is relatively more advantageous in terms of converting savings into investments, efforts giving more weight to stock markets, financing innovations and dynamic industries.

In Turkey, increasing interest of investors' behavior for the capital markets, and the strengthening of Turkey's position in global financial markets will provide new companies and small and medium-sized firms benefit from capital market instruments that they could not take their advantage before. In this way, the "creative destruction" process can be mobilized and the possibility of financing the production of new technologies in more developed financial markets may occur. Moreover, such a transformation will consolidate Turkey's leading position in the geography where it is located and will be consistent with the Istanbul International Finance Center project target that enables it to compete with developed centers.

In addition to the development of mutual funds and individual pension funds, an increase in interest for individual capital market instruments and the funds managed by institutional investors will contribute greatly to the development of Turkish financial markets. Especially, the Turkish economy has to realize very serious structural transformations within the framework of escaping from the middle-income trap. The savings gap must be closed for this conversion. In order to increase the savings, the capital markets have to increase breadth and depth. One of the steps taken by the Turkish economy to increase savings is the introduction of a compulsory pension system. The government contribution to both voluntary and compulsory individual pension systems provides incentives to increase savings. On the other hand, another factor that is important in the raising of savings in Turkey's economy is to bring a cushion of capital into the financial system. It is necessary to take into account the interest sensitivity of the conservative sector which has a significant share among those who have these savings.In this respect, efforts are needed to stimulate the demand for ethical investment instruments. Therefore, both the individual and the institutional investor that will operate the funds should be encouraged in the mentioned direction. From such a transformation, we can say that all financial market actors will be positively affected. Therefore, the development of stock markets will increase the banking system and thus, as a result of an increase in the development level of the whole financial system, macroeconomic growth will be accelerated.

As a result of the foregoing analysis in Turkish economic review, we think that the question in our title "BankBased versus Market-Based Financial System: Does it Really Matter?" should be answered with "Yes it does".

\section{References}

Aggarwal, R., Goodell, J. W., (2016). National preferences for bank or market finance, Economic Commentary, No. 2016-04, May.

Aivazian, V., Booth, L., (2003). Do emerging market firms follow different dividend policies from U.S. firms?,The Journal of Financial Research, Vol. XXVI, No. 3, Fall, University of Toronto Sean Cleary Saint Mary's University, pp. 371-387.

Akdoğan, N., Gülhan, O., Aktaş, M., (2017). The relationship between corporate responsibility reporting and corporate governance: Evidence from Turkish banking sector, Journal of Modern Accounting and Auditing, May, Vol. 13, No.5, pp. 181-195.

Allen, F. \& Gale, D. (1995). A welfarecomparison of intermediariesandfinancialmarkets in Germany andthe US, EuropeanEconomicReview, Vol. 39, February, pp. 179-209.

Allen, F. \& Gale, D. (1999). Diversity of opinionandfinancing of newtechnologies, Journal of Financial Intermediation, Vol. 8, pp. 68-89.

Allen, F., Bartiloro, L., \&Gu, X., (2018). Does economic structure determine financial structure?, Retrieved from https://spiral.imperial.ac.uk/bitstream/10044/1/63022/2/ABGK_accepted_JIE_11Aug18.pdf(Accessed: 30.12.2018).

Allen, F., Gale, D., (2001). Comparative financial systems: A survey, April, Retrieved from http://citeseerx.ist.psu.edu/viewdoc/download?doi=10.1.1.572.5460\&rep=rep1\&type=pdf (Accessed:30.12.2018)

Altıntaş,

\&Ayriçay,

Y., Türkiye'definansalgelişmeveekonomikbüyümeilişkisininsınırtestiyaklaşımıylaanalizi: Anadolü̈niversitesiSosyalBilimlerDergisi, 10 (2), pp. 71-98.

Aydın, H. İ., et. al. (2006). Corporate sector financial structure in Turkey: A descriptive analysis, Research and Monetary Policy Department Working Paper No:06/07, December.

Bechtold, H. (2014). Banken, kapitalmarkt, finanzierung der wirtschaftundverbriefung, Kreditwesen, Nummer: 940, pp. 18-21.

Berglöf, E. (1997). Reforming corporate governance: Redirecting the European agenda, Economic Policy, Vol. 12, No.24, April, pp. 91-123.

Bernet, B. (2003). Institutionellegrundlagen der finanzintermediation, München: R. OldenburgVerlag.

Boehmer, E., (1999). Corporate governance in Germany: Institutional background and results, Working Paper, HumboldUniversität: Berlin. 
Bolton, P., \&Thadden, E., 1998. Blocks, liquidity and corporate control, Journal of Finance, Vol. 53, No.1, February, pp. 1-25.

Choi, C.,\& Park, K., (2018). Financial system and housing price, Emerging Markets Finance and Trade, Vol. 54, No. 2, pp. 328-335.

CreditreformRating AG. (2014). KreditfondsalsalternativeAnlageform, Financial Research, 29 September, Retrieved from https:/www.creditreform-rating.de/pub/media/global/page_document/14-0929_Kreditfonds_als_alternative_Anlageform.pdf. (Accessed: 21.11.2018)

Demirguc-Kunt, A., Feyen, E., \& Levine, R., (2011). The evolving Importance of banks and securities markets, World Bank Economic Review, Retrieved from http://faculty.haas.berkeley.edu/ross_levine/papers/Evolving_Importance_WBER_forthcoming.pdf (Accessed: 07.01.2019)

Demirgüç-Kunt, A.\& Levine, R., (1999). Bank-based and market-based financial systems: Cross-Country comparisons, June. Retrieved from Https://Pdfs.Semanticscholar.Org/18e5/660bef2325f326bb8077bd0dd6f5225b1bf8.Pdf(Accessed: 18.12.2018)

Demirgüç-Kunt, A., \& Levine, R., (1996). Stock market development and financial intermediaries: stylized facts, World Bank Economic Review, Vol. 10, Iss. 2, May, pp. 291-321.

Emunds, B. (2003). Markt- vs. bankendominiertesFinanzsystem - einVergleich, Retrieved from www.attac.de/finanzmaerkte/fundgrube/emunds-Vergleich_Finanzsysteme.pdf., (Accessed: 02.01.2009).

EuropäischeKommissionGeneraldirektionWirtschaftundFinanzen, (2001).Die EU wirtschaft: Jahresbilanz 2001 investitionen in dieZukunft, EuropäischeWirtschaft, Nummer 73.

Fufa, T. \& Kim, J., (2018). Stockmarkets, banks, andeconomicgrowth: Evidencefrommorehomogeneouspanels, Research in International Business and Finance, Vol. 44, April, pp. 504-517.

Gerschenkron, A. (1962). Economicbackwardness in historicalperspective, a book of essays, Cambridge: Mass, BelknapPress of Harvard UniversityPress.

Gezer, M. A. (2018). Therelationshipbetweenfinancialdeepeningandeconomicgrowth: Bootstrapcausalityapproach fort he selecteduppermiddleincomecountries, TheoricalandAppliedEconomics, Vol. XXV, No. 1 (614), pp. 95-112.

Hackethal, A. \&Schmidt, R., (2000). FinanzsystemundKomplementarität, WorkingPaper Series: Finance and Accounting, No. 50, Frankfurt am Main: Universität Frankfurt. Retrieved from

https://www.clevelandfed.org/newsroom-and-events/publications/economic-commentary/2016-economiccommentaries/ec-201604-national-preferences-for-bank-or-market-financing.aspx(Accessed: 31.12.2018)

Handke, M. (2011). Die Hausbankbeziehung, Berlin:LITVerlag.

Hügle, W. (2001). Finazsysteme, wirtschaftlicheswachstumunddie rolle desstaates: Einefunktionaleransatzunterberücksichtigung der reformerfahrunglateinamerikanischerländer, Dissertation, Universitätzu Köln.

ICSA Emerging Markets Committe, (2015). Market-based financing in emerging market countries, April. Retrieved from http://www.amib.com.mx/images/Study\%20on\%20EMC\%20Market\%20Based\%20Finance.pdf, (Accessed: 10.01.2019)

Jackson, G., \&Vitols, S., (2001). Pension regimes and financial systems: Between financial commitment, market liquidity, and corporate governance. Retrieved from https://pure.mpg.de/rest/items/item_1234813/component/file_1234812/content (Accessed: 30.12.2018)

Kirchner, F. (2010). DieKonfigurationvonwirtschaftssystemen: Eininternationalervergleich, WSI Mitteilungen: 8.

Klein, D. (1998). Dieeuropäischenbankensysteme am vorabenddes Euro, Kreditwesen, Heft: 9, 1998, pp. $470-475$.

Lee, B-S. (2010). Bank-based and market-based financial systems: Time-series evidence, Pasific-Basin Finance Journal, 20 (2), pp. 173-197.

Levine, R. (2003). Finance andGrowth: Theory, Evidence, andMechanisms, University of Minnesota.

Levine, R., (2002). Bank-based or market-based financial systems: Which is better?,Journal of Financial Intermediation, 11, pp. 398-428.

Lizethe, M.\& Steven O., (2018). Finance and growth: Re-loaded, CFS Working Paper Series, No. 604, Goethe University, Center for Financial Studies (CFS), Frankfurt a. M.

Myers, S. (1984). Thecapitalstructurepuzzle, Journal of Finance, Vol. 39, pp. 575-592.

Pagano, M. et. al. (2014). Is Europe overbanked?, Reports of the Advisory Scientific Committe, ESRB, European Systemetic Board, No.4, June.

Papenfuss, H. (1999). BeschreibungsmodifürFinanzsysteme, Frankfurt: Peter Lang.

Passarge, E. M. (2010). Institutionellerwandel im finanzsystemDeutschlands: Vom bank- zum marktbasiertenmodell?, BambergerBeiträgezurSoziologie, Bamberg: University of BambergPress. 
Prowse, S. D., (1996). Corporate finance in international perspective: legal and regulatory influences on financial system development, Economic and Financial Policy Review, Federal Reserve Bank of Dallas Economic Review, Iss. Q III, pp. 2-15.

Rajan, R. G., \&Zingales L., (2001), Financial systems, industrial structure, and growth, Oxford Review of Economic Policy, Vol. 17, No. 4, pp. 467-482.

Rybczynski, T., (1983). The industrial finance systems; Europe, U.S., and Japan, IUI Working Paper, No. 113, The Research Institute of Industrial Economics (IUI), Stockholm.

Schackmann-Fallis, K. P., Schulz, H., (2015). Bank-versusKapitalmarktfinanzierung, in Mittelstand - Motor undZukunft der deutschenWirtschaft: Erfolgskonzeptefür Management, FinanzierungundOrganisation, (Ed) GeorgFahrenschon, ArndtGünterKirchhoff, Diethard B. Simmert, SpringerGabler: Wiesbaden, pp. 219-230.

Schmidt, R. H., \& Spindler, G., (2002). Path dependence, corporate governance and complementarity, International Finance, 5:3, pp. 311-333.

Schwiete, M. (1998). Finanzsystemeundwirtschaftlicheentwicklung: Theoretischeaspekte, vergleichwestlicherfinanzsystemeundsystemtransformation in Osteuropa, Berlin: Duncker\&Humblot.

Valickova, P., Havranek, T., \&Horváth, R., (2013). Financial development and economic growth: A meta-analysis, IOS Working Papers, No. 331, InstitutfürOst- und Südosteuropaforschung (IOS), Regensburg.

Vitols, S. (2001). The origins of bank-based and market-based financial systems: Germany, Japan, and the United States, Discussion Paper, FS I 01-302, Wissenschaftszentrum Berlin fürSozialforschung, January.

Vitols, S. (2003a). Varietiesofcapitalism und pensionsreform: Wird die Riester-Rente Deutschlands koordinierte marktwirtschafttransformieren?,Oesterreichische Nationalbank, Berichte und Studien, Wien, Heft 2, pp.174181.

Vitols,

S. $\quad$ (2003b).

Verhandeltershareholdervalue: DieDeutschevarianteeinerAngloamerikanischenpraxis, Wissenschaftszentrum Berlin fürSozialforschung: Berlin, Januar,2003, https://www.wzb.eu/www2000/alt/ism/people/misc/vitols/pdf/verhandelter_shareholder_value.pdf.

Vitols, S. (2004). Changes in Germany's bank-Based financial system: A varieties of capitalism perspective, WZB Discussion Paper, No. SP II 2004-03, Wissenschaftszentrum Berlin fürSozialforschung, March.

ZEW (ZentrumfürEuropäischeWirtschaftsforschung). (2013). Trennbanken: Eineanalytischebewertungvontrennbankelementenundtrennbankensystemen im hinblickauffinanzmarktstabilität, Abschlussberichtfür den BundesverbandÖffentlicher Banken DeutschlandsMannheim, 15. Januar.

Zogning, F. (2017). Comparingfinancialsystemssroundthe World: Capitalmarkets, legal systems, andgovernanceregimes, Economics, Management, and Financial Markets, 12 (4), pp. 43-58.

WEB Sites:

https://www.theglobaleconomy.com/rankings/bank_assets_GDP/

https://www.theglobaleconomy.com/rankings/domestic_credit_private_sector/

https://data.worldbank.org/indicator/CM.MKT.LDOM.N̄O?end=2017\&locations=US\&start=2012

https://databank.worldbank.org/data/reports.aspx?source=2\&series=CM.MKT.TRAD.GD.ZS

Basak Turan Icke She received her bachelor's degree in 1996 from Istanbul University, Faculty of Political Sciences, Department of Business Administration. In the same year she started to work as a research assistant in Istanbul University. She received her masters degree in 1999 in finance in the same university. She got her Ph. D. in 2006 in Accounting and Finance from Marmara University. The topic of her Ph.D thesis was mergers and acquisitions in Borsa Istanbul companies. Currently the author is working as an associate professor in Istanbul University, Faculty of Political Sciences. Her recent publications include two books on socially responsible investment and financial literacy. She has articles, chapters in edited books and other publications on mergers and acquisitions, behavioral finance, efficient market hypothesis, firm valuation.

Mehmet Akif Icke He received his bachelor's degree in 1992 from Istanbul University, Faculty of Political Sciences, Department of Public Administration. He started to work as a research assistant in Istanbul University in 1993. He received his masters degree in 1995 in economics from the same university. He got his Ph.D. in 2002 in Economics from Istanbul University. The topic of his Ph.D thesis was European Monetary Union and Possible Effects on Turkish Economy. Currently the author is working as an associate professor in Istanbul University, Faculty of Political Sciences. His areas of interest include European Monetary Union, ethics, financing of innovation, macroeconomics. He has articles, chapters in edited books and other publications on regional financial integration, corporate governance, global financial crises. 